\title{
Analysis of the determinants and typology of hydrometeorological disaster in Sukajaya Subdistrict, Bogor Regency, West Java, Indonesia
}

\author{
Yossa Istiadi \& Dolly Priatna
}

Study Programme of Environmental Management, Graduate School of Pakuan University, Jl. Pakuan Kotak Pos 452, Bogor 16129, Indonesia

Corresponding author: Dolly Priatna, dollypriatna@unpak.ac.id

\begin{abstract}
The objective of this research is to determine the factors as a typology of hydrometeorological disasters. The research method employed is post-disaster survey activities through hypothetical descriptions from October to December 2020. The analysis technique uses factor analysis on five variables, namely runoff, infiltration, slope, land cover, and infrastructure. The data retrieval obtained nine areas of landslide disaster points along 20 kilometers from Kiarapandak Village to Cisangku Village, Sukajaya Subdistrict, Bogor Regency, one of which were the areas affected by landslides in January 2020. From the factorial analysis results, it was found that the five variables above were suitable as a factor for determining disaster based on correlation values (r), that includes Factor 1 which is the variable of land slope (0.855) and the infrastructure variable (0.872). Factor 2 is water infiltration (0.928), water runoff $(0.269)$, and land cover $(0.717)$. In conclusion, the typology of hydrometeorological disasters is distinguished based on two determinants, firstly the physical construction of land, slopes, as well as infrastructure of road and river. Secondly, factors of water flow, water infiltration, runoff, and land cover.
\end{abstract}

\begin{abstract}
ABSTRAK
Tujuan penelitian adalah membuat determinasi faktor-faktor sebagai tipologi kebencanaan hidrometeorologi. Metode penelitian melalui kegiatan survey pasca bencana melalui deskripsi hipotetik pada bulan Oktober-Desember 2020. Teknik analisis menggunakan analisis faktor pada 5 (lima) variabel yaitu limpasan, resapan, kemiringan, tutupan lahan, dan infrastruktur. Pengambilan data mendapatkan 9 (sembilan) daerah titik bencana longsor sepanjang 20 kilometer dari Desa Kiarapandak sampai Desa Cisangku, Kecamatan Sukajaya Kabupaten Bogor, yang merupakan wilayah terkena bencana longsor pada bulan Januari 2020. Dari hasil analisis faktorial diperoleh bahwa 5 (lima) variabel di atas layak dijadikan faktor determinasi kebencanaan berdasarkan nilai korelasi (r), meliputi Faktor 1 adalah variabel kemiringan lahan (0,855) dan variabel infratruktur (0,872). Faktor 2 adalah resapan air (0,928), limpasan air (0,269), dan tutupan lahan (0,717). Kesimpulan, tipologi bencana hidrometeorologi dibedakan berdasarkan dua faktor determinasi yaitu pertama faktor konstruksi fisik lahan, kemiringan dan infratruktur jalan dan sungai, dan faktor aliran air, resapan air, limpasan, dan tutupan lahan.
\end{abstract}

Keywords: hydrometeorology, rainfall, landslide disaster, Bogor Regency

\section{INTRODUGTION}

Current climate change is also suspected of causing an increase in hydrometeorological disasters such as floods, landslides and tornadoes. Currently, flooding is a problem that is also a major concern throughout regions in many countries. This problem is exacerbated by global climate change. Several climate projection models predict that the greenhouse effect will influence the hydrological cycle. High rainfall will directly affect the expansion of flood inundation areas in the lowlands (Rosyida et al., 2019).

Hydro-climatological disaster categories consist of (1) flood runoff, and (2) landslides. Flood runoff comes from runoff that flows through rivers or becomes a puddle. Whereas runoff is the flow of water flowing on the ground surface caused by rainfall after the water experiences infiltration and evaporation, then flows

Submitted 10 March 2021; Accepted 22 March 2021. into rivers (Hadisusanto, 2011). Furthermore, it is stated that the form of flood hydrograph in a catchment area is determined by two things, such as: 1) characteristics of heavy rain, namely the distribution of rain intensity in time and space., and 2) characteristics of the catchment area e.g., area, shape, channel system and land slope, type and distribution of soil layers as well as geological and geomorphological structures.

Whereas in the category of landslides, soil movements are directly related to various natural physical properties such as geological structure, parent material, soil, drainage patterns, slopes/landforms, rain and dynamic non-natural properties such as land use and infrastructure (Barus, 1999). According to Suripin (2002) landslides are a form of erosion where the transportation or movement of the soil mass occurs at a time in a relatively large volume. Wang et al. (2017) stated that the occurrence of landslides is related to 
various factors such as precipitation, geology, distance from the fault, vegetation, and topography.

Bogor Regency has a considerably large potential for natural disasters in West Java Province, especially natural disasters such as hydrometeorological floods and landslides, this is because of rain with very high intensity and with high topography has the potential to cause runoff and land shifts that result in landslides. According to BPBD Bogor Regency, there are 15 subdistricts with high potential for natural disasters including Sukaraja, Tamansari, Megamendung, Cisarua, Suka Makmur, Cariu, Cigudeg, Leuwiliang, Tamansari, and the western region of Bogor Regency which geographically consists of hills.

In the formulation of disaster handling and management, research on typology based on general dimensions is needed that is not only across different sources of disasters, but also between the same sources of disaster (Quarantelli, 1987). For this reason, this research is compiled to conduct a typology diagnosis of disasters with symptoms of a disaster by studying the impacts that occur both on the community, infrastructure, and public facilities as well as the supporting devices. From the description above, the problem formulation that can be taken is, "What is the typology of disasters that occurred in various regions based on the type of hydrometeorology?. Moreover, what are the determinants of disasters based on typology of hydrometeorological disasters?".

The core structure in a disaster typology study consists of three important layers. The first layer or the basic description timeline of the disaster event includes the core pre-event, event, and post-event. The second layer is about expansion of each core, and the third layer introduces the concept of "strengthening resilience".

Each layer consists of studies on the pre-event, event, and post-event phases. The pre-event is the status of the community about hazards and risks, the event stage is about damage and its consequences, disturbances, changes in function, response, rescue, and assistance, while the post-event stage is about recovery and reconstruction, and renewal (Wong et al., 2017).

Qodriatun (2013) stated that hydrometeorological disaster is a term of disaster caused by meteorological parameters (rainfall, humidity, temperature, and wind). These types of disasters include drought, flood, storm, forest fire, El Nino, La Nina, landslide, tornado, whirlwind, typhoon, cold wave, heat wave, fohn wind (gending wind, brubu wind, bohorok wind, and kumbang wind).

Parameters of disaster factors can be distinguished as (1) Land Slope; based on the analysis of land slope calculations, the landslide susceptibility is divided into four classes, namely $0-15 \%, \quad 15-25 \%, 25-45 \%$, $45-65 \%,>65 \%$. Weight/scoring of each slope classification shows that the steeper the relief, the greater the weight, so that it will result in a greater vulnerability value. (2) Land Cover; based on the results of land cover analysis, there are four classes of land cover in the Bogor Regency, namely high, rather high, medium, rather low and low. This land cover class shows that the lower the land cover class (category), the better the land cover, so that it is more effective in controlling landslides compared to high land cover classes (categories). (3) Runoff; flood comes from runoff that flows through a river or becomes a puddle. Whereas runoff is the flow of water flowing on the ground surface caused by rainfall after the water experiences infiltration and evaporation, then flows into rivers (Hadisusanto, 2011).

According to (Suripin, 2004), flooding is a condition in which water cannot be accommodated in the drainage channel (riverbed) or water is blocked in the drain, which cause it to overflows the surrounding area (flood plain). (4) Soil Infiltration; infiltration is the process of infiltrating water or the process of infiltrating water from the soil surface through soil pores. From the hydrological cycle, some rainwater that falls on the ground will seep into the ground, in which some will fill the surface basin and the remaining will become an overland flow. The speed of rainwater entering the soil surface is influenced by the type and texture of the soil.

Based on the description above, the parameters that can be used in assessing the typology of landslide disasters including soil infiltration, water runoff, land cover or canopy, slope, and the medium for composing the physical structure of the land (soil type, geological rock).

\section{METHODS}

The type of the research is a descriptive survey through hypothetical analysis techniques and factorial analysis (Sugiyono, 2010). The research location is in the administrative area of Bogor Regency, West Java Province (Figure 1). Geographically, Bogor Regency has a varied geographical type of area, from relatively low plains in the northern area to highlands in the southern part, which is around $29.28 \%$ at elevation of 15-100 meter above sea level ( $\mathrm{m}$ asl), $42.62 \%$ at elevation of $100-500 \mathrm{~m}$ asl, $19.53 \%$ are at an elevation of $500-1,000 \mathrm{~m}$ asl, $8.43 \%$ at $1,000-2,000 \mathrm{~m}$ asl, and the rest of $0.22 \%$ at elevation of 2,000-2,500 m asl. Bogor Regency is located at the position between $6^{\circ} 19^{\prime}$ and $6^{\circ} 47^{\prime}$ South Latitude, as well as between $106^{\circ} 01^{\prime}$ and $107^{\circ} 103^{\prime}$ East Longitude.

According to the Administrative Map of Bogor Regency and data from BPS Bogor Regency in 2019, the area of Bogor Regency is 2,663.81 km², with an administrative area consisting of 40 Subdistricts. In terms of area, Jasinga Subdistrict is the largest (208.06 $\mathrm{km}^{2}$ ), followed by Cigudeg Subdistrict $\left(158.89 \mathrm{~km}^{2}\right)$. 
The subdistrict with the smallest area is Ciomas Subdistrict $\left(16.30 \mathrm{~km}^{2}\right)$. This research was conducted from October to December 2020.

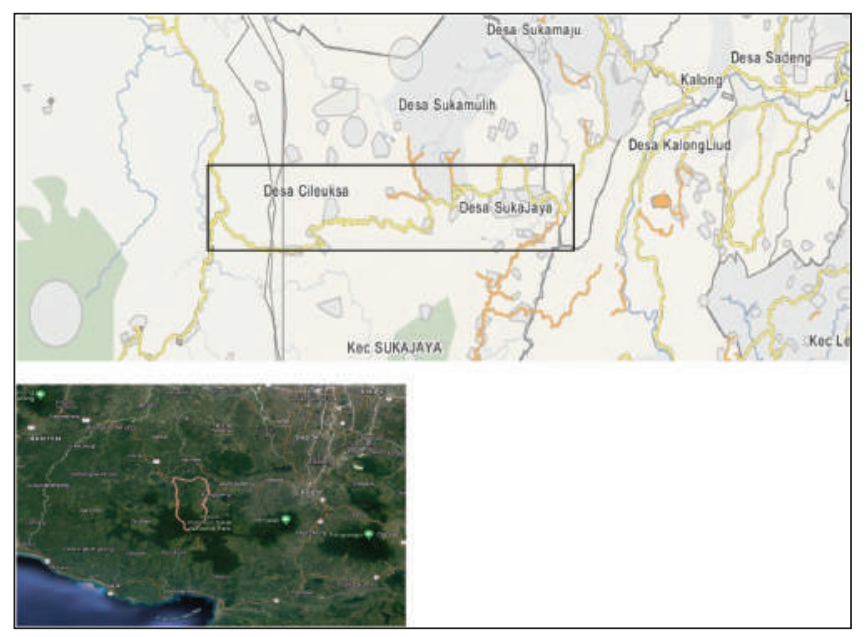

Figure 1. Location of landslide research in Sukajaya Subdistrict, Bogor Regency.

\section{RESULTS AND DISGUSSION}

General description of the physical typology of landslides in Sukajaya Subistrict, Bogor Regency was obtained through surveys and hypothetical depiction of a catastrophic event that has occurred 6-12 months after the event. Based on the length of the observation area, which include along $20 \mathrm{~km}$ area between the villages of Kiara Sari to Cerewed and towards 16 landslide points, it was obtained that nine locations of landslide profiles were identified to be in the observable category. After the landslide disaster, access to transportation and mobility has been repaired both permanently and on a limited basis.

In general, the description of landslides is an event of movement of the land surface caused by high rainfall and triggered by road and river structure media (Dewi \& Istiadi, 2016). The physical characteristics of land with a slope of more than $60^{\circ}$ have a vulnerability and a threat to the magnitude of landslides that occur. The

Table 3. Scores of landslide disaster parameters for each variable at each point of disaster location.

\begin{tabular}{|c|c|c|c|c|c|c|}
\hline \multirow{2}{*}{ No. } & \multirow{2}{*}{ Location } & \multicolumn{5}{|c|}{ Scoring } \\
\cline { 3 - 7 } & & $\begin{array}{c}\text { Infiltration } \\
(\mathbf{P 1})\end{array}$ & $\begin{array}{c}\text { Runoff } \\
(\mathbf{P} 2)\end{array}$ & $\begin{array}{c}\text { Ganopy } \\
(\mathbf{P 3})\end{array}$ & $\begin{array}{c}\text { Slope } \\
\mathbf{( P 4})\end{array}$ & $\begin{array}{c}\text { Infrastructur } \\
\mathbf{e} \\
(\mathbf{P 5})\end{array}$ \\
\hline 1 & 1.7 & 4 & 2 & 3 & 5 & 3 \\
\hline 2 & 2.1 & 2 & 2 & 2 & 5 & 3 \\
\hline 3 & 5.6 & 1 & 2 & 1 & 5 & 4 \\
\hline 4 & 7.1 & 3 & 4 & 4 & 3 & 1 \\
\hline 5 & 8.1 & 2 & 2 & 2 & 5 & 4 \\
\hline 6 & 10.3 & 2 & 3 & 3 & 3 & 3 \\
\hline 7 & 11.2 & 2 & 3 & 4 & 4 & 2 \\
\hline 8 & 11.5 & 3 & 2 & 3 & 4 & 2 \\
\hline 9 & 12.1 & 2 & 2 & 2 & 2 & 3 \\
\hline
\end{tabular}

condition of the soil structure that becomes a catalyst in this landslide disaster is related to the soil substrate, the amount of vegetation cover, land use, water infiltration, and water runoff when it rains.

Land use patterns tend to have the potential to weaken the strength of the soil structure, especially the designation of settlements, secondary crops on non-cultivated land, unmanaged shrublands, in the absence of runoff flows in the soil structure, especially in infrastructure media such as roads and bridges.

The area of Sukajaya Subistrict is a hilly area between Cidurian River and tributaries of Cikatomas River, and various other tributaries. The road access between Kiara Sari and Cisangku is the main access road which has a busy traffic frequency level for the mobility of people and goods in more than 12 densely populated villages. Nevertheless, the road condition is not equipped by adequate drainage facilities, so that causing water runoff which gives vulnerability to the strength of the road structure.

The recording of landslide physical typology includes land slope, landslide length and width, land use, ownership, infiltration, canopy cover, and runoff. Based on the results of the observations, it can be explained that the nine landslide locations are as follows (Table 1).

Data analysis through SPSS 16.5 shows that the KMO MSA value is 0.614 which means this value $>$ 0.50 and the result of Bartlett's test of sphericity (sig.) value is $0.049<0.05$. Therefore the factor analysis in this study can be continued because it fulfills the first requirement. The table "Anti-image Matrices" to 
determine the appropriate variable, it is known that the value of the MSA (Measure of Sampling Adequacy) is: (1) Infiltration of 0.575 ; (2) Runoff of 0.618 ; (3) Canopy of 0.634 ; (4) Slope of 0.617 ; (5) Infrastructure of 0.717 .

In this research we use five variables which means five components are analyzed. There are two types of analysis to explain a variant, namely Initial Eigenvalues and Extraction Sums of Squared Loadings. The Initial Eigenvalues variant shows the formed factors. If all the factors are added up, it shows the variable (3.021+ $1.132+0.577+0.152+0.118=5$ variables $)$. Meanwhile, the Extraction Sums of Squared Loadings section shows the number of variations or the number of factors that can be formed. In the output results above, there are 2 (two) factor variables, those are 3.021 and 1.132 .

Based on the table total output of Variance Explained in the "Initial Eigenvalues" section, there are 2 (two) factors that can be formed, where the requirements to be a factor states that the Eigenvalues value must be $>$ 1. The Eigenvalue Component 1 is 3.021 or $>1$ then it becomes a factor of 1 and is able to explain 60,426\% variation. While the value of Eigenvalue Component 2 is 1.132 or $>1$, it becomes a factor of 2 and is able to explain $83.071 \%$ of the variation (Figure 2). The total component value $3,4,5$ is not calculated because their Eigenvalues is $<1$.

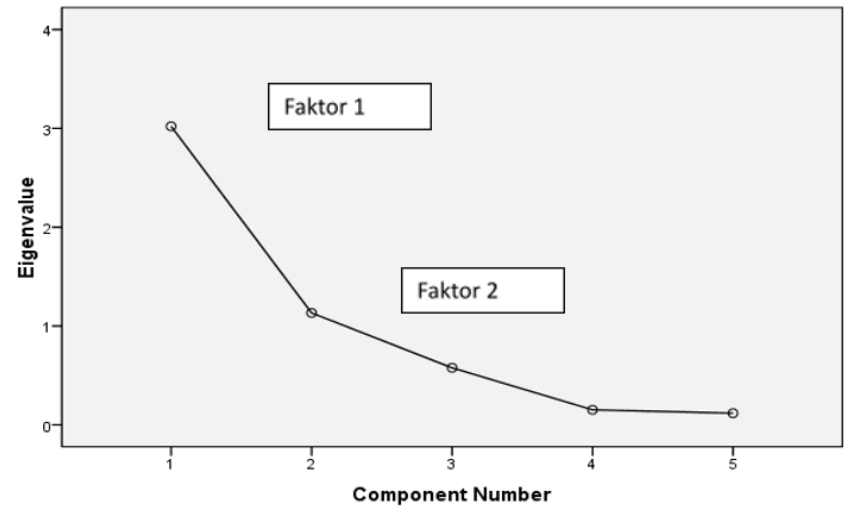

Figure 2. Scree plot to show the number of factors formed.

Table 2. The Rotated Component Matrix table shows the amount of variable correlation based on the components of the formed factors, namely Factor 1 and Factor 2.

\begin{tabular}{|l|c|c|}
\hline \multirow{2}{*}{} & \multicolumn{2}{|c|}{ Component } \\
& 1 & 2 \\
\hline Infiltration & .005 & $\mathbf{. 9 3 8}$ \\
Runoff & -.821 & $\mathbf{. 2 6 9}$ \\
Canopy & -.611 & $\mathbf{. 7 1 7}$ \\
Slope & $\mathbf{. 8 5 5}$ & .159 \\
Infrastructure & $\mathbf{. 8 7 2}$ & -.350 \\
\hline
\end{tabular}

For ensuring of which factor is included in a group of factors, it can be determined by looking at the value of the largest correlation between the variable and the formed factor (component). How to read the results of the rotation model factor analysis is explain as follows (Table 2).

1. Infiltration variable. The correlation value of this variable with Factor $1=0.005$ and with Factor $2=0.938$, because the correlation value of Factor $2>$ Factor 1, so that the Infiltration variable is included into the group of Factor 2

2. Runoff variable. The correlation value of this variable with Factor $1=-0.821$ and with Factor $2=0.269$, because the correlation value of Factor $2>$ Factor 1, so that the Runoff variable is included into the group of Factor 2

3. Canopy variable. The correlation value of this variable with Factor $1=-0.611$ and with Factor $2=0.717$, because the correlation value Factor $2>$ Factor 1, so that the Canopy variable is included into the group of Factor 2

4. Slope variable. The correlation value of this variable with Factor $1=0.855$ and with Factor $2=0.159$, because the correlation value of Factor $1>$ Factor 2, so that the Slope variable is included into the group of Factor 1

5. Infrastructure variable. The correlation value of this variable with Factor $1=0.872$ and with Factor $2=-0.350$, because the correlation value of Factor 1> Factor 2, so that the Runoff variable is included into the group of Factor 1

Based on the factorial analysis results above, it is shown that two determinant factors are obtained, those are Factor 1 and Factor 2. Factor 1 is categorized as a factor of construction media characteristic, while Factor 2 as factor of natural characteristic. Natural characteristic variables include soil absorption power or soil infiltration variable, runoff variable which is the amount of water wasted on the soil surface, and canopy or land cover variable as the power to hold rainwater so that it doesn't fall directly to ground surface. The infiltration variable has a correlation of 0.958 , which means that it shows a close relationship or has the potential to influence the occurrence of landslides. The runoff variable has a correlation of 0.269 which is very closely related to landslides, although it is not considered as a cause. The variable of land cover or canopy has a correlation of 0.717 , which means that it has a tendency to influence the occurrence of landslides.

In the category of construction media characteristic factors, the slope variable has a correlation of 0.855 which indicates a very large potential for landslide effects. The infrastructure variable has a correlation of 0.872 which also shows a great potential as an influence 
for landslides.

In previous study that has been done on the determination of landslide vulnerability through the method Landslide Susceptibility Analysis (LSA) and by means of the calculation of the bivariate relationship, it shows the effect of different variables on the formation of landslide events. At a high level of vulnerability it can affect $63 \%$, at a moderate level of vulnerability it can affect $26 \%$, and at a low level of vulnerability it can affect $11 \%$ for the occurrence of landslides on various variables, especially land slopes, land cover, and the presence of river structure media (Avci \& Esen, 2019). Therefore, in the typology pattern of landslide vulnerability, it is necessary to study the category of vulnerability level. According to the research, there are four categories which is based on landslide typology, those are (1) "no warning" category, (2) "alert" category, (3) "attention" category, and (4) the "warning" category (Susandi et al., 2018). This category is adjusted to the level of correlation between the variables which become the typology of the landslide disaster.

In the aspect of variable of artificial structure media, transportation assets such as vehicles and road infrastructure are the basic components in handling landslide disaster risks. This is revealed by Argyroudis et al. (2019) which is the results of their research explains that landslide vulnerability is a basic component of risk and an important understanding to characterize the reliability of assets and transportation infrastructure systems to mitigate risks. This provides an explanation of the existence of infrastructure media, especially roads and transportation flows, which are included in the category of Factor 1 that triggers landslides caused by large amounts of rain precipitation with a correlation level of $87 \%$.

Landslide disaster can also be distinguished based on their cause, such as based on geological earthquakes or caused by high intensity of rainfall. These two causes can occur simultaneously between geological earthquakes and high intensity of rainfall. During the occurrence of rain, rain water will enter into the rock bed in the soil then it can change the structure of the slope and soil surface which will increase the pressure of rainwater in the soil. The occurrence of land and rock landslides could change the formation of land slopes which will have an impact on the loss of roads or other natural formations such as rivers (Yang, 2018).

The previous elaboration shows that the catastrophe caused by high intensity of rainfall will also be accompanied by a geological earthquake which is characterized by land movement, and is stimulated by the characteristics of land slope, water infiltration into the ground, as well as characteristics of river infrastructure and transportation access in an area.

\section{GONGLUSION}

1. The typology of hydro-climatological disasters can be distinguished based on regional characteristic with the variable of levels of water infiltration by soil, land cover by vegetation canopy, water runoff in high intensity of rainfall, slope level, and infrastructure that consisting of soil texture and rock geology, as well as physical road construction or the existence of water from river stream.

2. Determinant factors of hydro-climatological disasters can be divided into two factors, namely land characteristics factor and ecological maintenance of rainfall factor. THESE two factors can be used as a combination of policies in mitigating of areas prone to hydro-climatological disasters.

\section{AGKNOWLEDGEMENTS}

The source of the funding of this research obtained from "Hibah Penelitian Dosen" of the University of Pakuan's Graduate School. We would like to express our thank to Prof. Dr. Ing. H. Soewarto Hardhienata (Dean of Graduate School) and Dr. Ani Iryani, MSi. (Head of LPPM at University of Pakuan).

\section{REFERENGES}

Argyroudis, S.A., Mitoulis, S.A., Winter, M.G. \& Kaynia, A.M. (2019). Fragility of transport assets exposed to multiple hazards: State-of-the-art review toward infrastructural resilience. Reliability Engineering \& System Safety 191: 106567. DOI: $10.1016 /$ j.ress.2019.

Avci, V. \& Esen, F. (2019). Determination of landslide susceptibility in the Melet River basin (Rrdu, Turkey) by bivariate statistical analysis method. Fournal of Eurasia Social Sciences 10 (35): 42-75.

Barus, B. (1999). Pemetaan bahaya longsoran berdasarkan klasifikasi statistik peubah tunggal menggunakan SIG: Studi kasus daerah Ciawi-Puncak-Pacet, Jawa Barat. Furnal Ilmu Tanah dan Lingkungan 2 (1): 7-16.

Dewi, I.K. \& Istiadi, Y. (2016). Mitigasi bencana pada masyarakat tradisional dalam menghadapi perubahan iklim di kampung Naga, Kecamatan Salawu, Kabupaten Tasikmalaya. Jurnal Manusia dan Lingkungan 23 (1): 129-135.

Wong, D.F., Spencer, C., Boyd, L., Burkle, F.M. \& Archer, F. (2017). Disaster metrics: A comprehensive framework for disaster evaluation typologies. Prehospital and Disaster Medicine 32 (4): doi: 10.1017/S1049023X17006471.

Hadisusanto, N. (2011). Aplikasi Hidrologi. Jogja Mediautama, Yogyakarta. 
Qodriatun, S.N. (2013). Bencana hidrometeorologi dan upaya adaptasi perubahan iklim. Info Singkat Kesejahteraan Sosial V (10): 9-12.

Quarantelli. E.L. (1987). Disaster studies: An analysis of the social historical factors affecting the development of research in the area. International Fournal of Mass Emergencies and Disasters 5 (1): 7-32.

Rosyida, A., Nurmasari, R. \& Suprapto. (2019). Analisis perbandingan dampak kejadian bencana hidrometeorologi dan geologi di Indonesia dilihat dari jumlah korban dan kerusakan (Studi: data kejadian bencana Indonesia 2018). Jurnal Dialog Penanggulangan Bencana 10 (1): 12-21.

Sugiyono. (2010). Metode Penelitian Kualitatif, Kuantitatif dan $R \Xi^{2} D$. Alfabeta, Bandung.
Susandi, A., Tamamadin, M., Pratama, A., Faisal, I., Wijaya, A.R., Pratama, A.F., Pandini, O.P. \& Widiawan, D.A. (2018). Development of hydro-meteorological hazard early warning system in Indonesia. Fournal of Engineering \& Technological Sciences 50 (4): 461-478.

Suripin. (2002). Pelestarian Sumberdaya Tanah dan Air. Penerbit Andi, Yogyakarta.

Yang, J. (2018). Landslide damage from rxtreme rainstorm geological accumulation layers within Plain River basins. Journal of Coastal Research 82 (sp1): 1-11. DOI: 10.2112/SI82-001.1. 